\title{
Adaptation to climate change-related risks in Dutch urban areas: stimuli and barriers
}

\author{
Hens Runhaar • Heleen Mees • Arjan Wardekker • \\ Jeroen van der Sluijs $\cdot$ Peter P. J. Driessen
}

Received: 4 October 2011 / Accepted: 10 February 2012/Published online: 28 February 2012

(C) The Author(s) 2012. This article is published with open access at Springerlink.com

\begin{abstract}
Climate change is associated with various risks, such as flooding and heat stress. So far, most research has concentrated on the identification and quantification of these risks as well as the development of adaptation measures. Yet much less is known about how planners actually perceive and deal with climate change, and why. This paper focuses on the governance of two climate change-related risks in urban areas in the Netherlands, namely heat stress and flooding from rainfall and rivers. Heat stress hardly seems to be perceived as an urgent problem, mainly because there is no clear 'problem owner'. Because municipalities are responsible for rain and sewage water management and partly for river flooding, increased flood risk is more often recognised as a (potential) problem. Despite the rather low sense of urgency regarding these two climate changeinduced risks, urban planners are, or envisage, investing in more open water and public green areas. Heat stress and flood risks from rainfall are not the reasons per se, but primarily act as additional arguments to legitimise these measures, which should contribute to sustainable urban development in general. Our analysis suggests a gap between the perceived urgency of proactive adaptation to climate change by scientists and the perceptions of planners. Climate science research could enhance its contribution to urban planning by providing conceivable projections of climate change impacts as well as by developing
\end{abstract}

Electronic supplementary material The online version of this article (doi:10.1007/s10113-012-0292-7) contains supplementary material, which is available to authorized users.

H. Runhaar $(\bowtie) \cdot$ H. Mees · A. Wardekker · J. van der Sluijs .

P. P. J. Driessen

Utrecht University, Utrecht, The Netherlands

e-mail: h.a.c.runhaar@uu.nl adaptation measures that serve multiple purposes and strategies to successfully implement these.

Keywords Climate change $\cdot$ Risk $\cdot$ Heat stress . Flooding $\cdot$ Adaptation $\cdot$ Urban planning

\section{Introduction}

Climate change is associated with a number of risks, such as flooding, heat stress, storms and vector- and rodent-borne diseases (Butler and Harley 2009; Huynen en Van Vliet 2009; PBL 2009). While in most cases, climate change will amplify (mostly already existing) risks, in some cases, beneficial impacts are envisaged (e.g. reduced winter mortality due to higher temperatures; Kabat et al. 2005; PBL 2009). However, the general impression in the scientific community seems to be that, overall, climate change requires the timely development and implementation of adaptation plans (e.g. Adger and Barnett 2009; Kabat et al. 2005; PBL 2009). Referring to the Katrina hurricane example, Kabat et al. (2005) claim that the economic consequences of not being prepared for changing weather patterns may be huge, in particular in densely populated, economic areas. In addition, ex ante evaluations have shown that planned adaptation to flood risk yields positive benefit-to-cost ratios (Tompkins et al. 2010).

In this paper, we focus on climate change-related impacts on urban areas in the Netherlands and in particular on how urban planners (i.e. politicians and their staff) actually perceive and deal with climate change. Municipalities are responsible for these risks in their territories; river flooding is a shared responsibility with the specialised state department as well as water boards. However, 
literature suggests that urban planners have not (yet) been very active in recognising the impacts of climate change in their territories and in developing adaptation strategies. For instance, Mulder et al. (2009) wonder why heat stress has not been much of an issue in the Netherlands, especially after the 2003 heat wave that had a range of unanticipated impacts. Groot et al. (2008) observe that adaptation is not an issue in the Dutch construction sector. Also outside the Netherlands, urban planners seldom have plans that anticipate climate change-related risks, such as heat stress or intensified storms (e.g. Bernard and McGeehin 2004; Bulkeley 2009). Demeritt and Langdon (2004) and Tompkins et al. (2010) observe that in the UK (by 2004-2005), climate change adaptation in general has not received much attention from urban planners (yet), and even less from private actors. Bulkeley (2010) observes that climate change does receive attention from municipalities worldwide, but their policies tend to concentrate on mitigation, rather than on adaptation. Similar findings are reported by Wheeler (2008) and Bassett and Shandas (2010).

So far, however, little has been written in the academic literature on how urban planners perceive and deal with climate change and how that can be explained (Urwin and Jordan 2008). In this paper, we aim to contribute to adaptation literature by means of an empirical analysis. More particularly, we analyse how urban planners in the Netherlands deal with two climate changerelated risks in urban areas, namely heat stress and flooding from rainfall and rivers. These risks are considered two of the main challenges in urban areas in the light of climate change (PBL 2009), but with different societal consequences (i.e. primarily health versus primarily material damage). Three questions are addressed in this paper: (a) To what extent are the risks of intensified heat stress and flooding recognised as urgent by urban planners? (b) What kind of adaptation measures are proposed or actually used for adapting to intensified heat stress and flooding? (c) What factors stimulate or hamper problem recognition and implementation of adaptation measures? With this study, we aim to contribute to the limited knowledge on adaptation at the local level and in particular on the stimuli for and barriers to developing adaptation strategies. Although the findings are to some extent unique to the Netherlands, our analytical framework allows for comparative studies in space as well as in time.

In Sect. 2, we summarise the projected impacts of climate change regarding heat stress and flooding in Dutch urban areas. In Sect. 3, our analytical framework is presented. In Sect. 4, we present our empirical findings from case studies as well as from interviews with experts. We discuss our main conclusions in Sect. 5.
Heat stress and flooding: expected challenges for urban areas in the Netherlands

\section{Heat stress}

Climate scenarios project increases in the frequency, duration and intensity of heat waves (IPCC 2007; Meehl and Tebaldi 2004). Without adaptation, this increases heat stress: heat-related mortality, disease and discomfort (sleep deprivation, e.g. affecting labour productivity). The relation between daily temperature and daily mortality is roughly V-shaped, with for the Netherlands a present-day optimum of $16.5^{\circ} \mathrm{C}$, and increasing mortality with higher and lower temperatures (Huynen et al. 2001). Warm and sunny weather also tends to worsen air pollution, which acts synergistically with heat stress, jointly causing a higher mortality than each factor alone (Fischer et al. 2004).

The 2003 European heat wave, resulting in some 40,000 excess deaths (García-Herrera et al. 2010), exemplifies an extreme event that may become more frequent if warming continues. In the Netherlands, an estimated excess of some 1,000-2,000 deaths occurred during that summer, approximately 500 of which occurred during the 14-day August heat wave (Fischer et al. 2004; Garssen et al. 2005). Some of these people would have died shortly anyway, referred to as the 'harvesting effect' or 'mortality displacement'. Estimates of the magnitude of this effect diverge. In the Netherlands, the harvesting effect has not been observed for all heat waves (Huynen et al. 2001). The impacts of the 2003 heat wave in the Netherlands were less dramatic than, for instance, those in France. This may be due to overall lower temperatures, and the highest temperatures occurring in relatively less densely populated areas, while in France, the heat wave mainly hit urban areas (Garssen et al. 2005) where heat stress risks are greater (Huynen and Van Vliet 2009).

The KNMI'06 climate scenarios (Van den Hurk et al. 2006) project a further increase of +0.9 to $+2.8^{\circ} \mathrm{C}$ for average summer temperatures in the Netherlands in 2050 (assuming +1 to $+2^{\circ} \mathrm{C}$ globally). Temperatures of +1.0 to $+3.6^{\circ} \mathrm{C}\left(+1.0\right.$ to $+3.8^{\circ} \mathrm{C}$ for the warmest day) are projected for the $10 \%$ warmest summer days (Van den Hurk et al. 2006). Projected changes in the number of tropical days $\left(\geq 30^{\circ} \mathrm{C}\right)$ are also greater than in summer days $\left(\geq 25^{\circ} \mathrm{C}\right)$. Factors such as humidity, wind speed, long/ shortwave radiation, clothing, activity, air conditioning prevalence, and housing characteristics are also relevant for 'thermal comfort' and the health impact of heat waves (e.g. Matzarakis and Endler 2010). Issues such as the readiness of the healthcare system (e.g. heat waves occur often during the summer, potentially occurring during healthcare staff holiday period) and behavioural and societal factors 
(e.g. (in)sufficient liquid intake, particularly for isolated elderly people) are also important. These issues are likely to be subject to autonomous adaptation, behaviourally as well as physiologically, but the extent and rate of such adaptations are not known. Huynen et al. (2008) indicate that by 2050 , increased heat stress in the Netherlands could imply hundreds of deaths per year. Changes in morbidity (e.g. hospital admissions) may be proportional or greater (MNP 2005; see also Kovats and Ebi 2006), although considerable uncertainties remain. Vulnerable groups include the elderly, chronically ill (e.g. cardiovascular and respiratory diseases, diabetes), socially isolated people, those with a lower socio-economic status and possibly very young children (Huynen et al. 2001; IPCC 2007; GarcíaHerrera et al. 2010).

Heat stress varies with the so-called 'urban heat island' effect, with urban temperatures tending to be higher than rural temperatures. For instance, in Rotterdam, differences have been reported between urban and rural background temperatures of up to $8^{\circ} \mathrm{C}$ during windless nights, with considerable differences between highly urbanised and green, low-rise neighbourhoods (Gemeentewerken Rotterdam 2011). The effect increases the number of hot days (and nights), duration of heat waves and, subsequent, mortality (Salcedo Rahola et al. 2009). Relevant factors in urban heat include material reflectivity (albedo) and thermal characteristics, evaporation (water, plants), shading, building density, wind patterns and blocking of 'urban ventilation' and heat-producing activities.

\section{Flooding}

Climate change could increase precipitation extremes, resulting in increasing risks of local superfluous water after downpours (small-scale, short-term) and river flooding (larger scale, longer term) (cf. IPCC 2007). Climate scenarios project increases in both flood risks. Flooded streets may cause nuisance and traffic disruption, while flooded buildings result in material damage. In extreme situations, impacts of flooding (and evacuations) may include deaths and injuries, societal disruption, mental health impacts, economic damage due to production standstill, indirect damage for economically connected areas and industries and health impacts due to moulds, for example released contaminants or infectious diseases (e.g. Huynen et al. 2008). Approximately, 59\% of the Netherlands is floodprone (from rivers and sea ${ }^{1}$ ), and the economic value at risk will increase due to urbanisation and the increasing value of existing assets $(+100$ to $+250 \%$ in 2040 compared to 2000 (PBL 2010)).

\footnotetext{
${ }^{1}$ About $29 \%$ of the $59 \%$ can be attributed to river flooding (source: Netherlands Environmental Assessment Agency).
}

During the past century, mean yearly precipitation has increased by $+18 \%$ (KNMI 2009). The number of days with considerable precipitation has increased as well (MNP 2005). However, year-to-year and interregional variability is large. The KNMI'06 scenarios project an increase in mean winter precipitation of +4 to $+14 \%$ in 2050 , with similar changes for winter daily and longer-period extremes. Changes in summer precipitation are uncertain, -19 to $+6 \%$. However, the intensity of showers is expected to increase, e.g. +5 to $+27 \%$ for the $1 / 10$-year daily precipitation sum. For the coastal regions, where many of the largest Dutch cities are located, the upper two scenarios for precipitation intensity $(+13$ to $+27 \%)$ are seen as most realistic, due to the effect of the nearby sea (KNMI 2009).

Discharge levels of the Rhine and Meuse rivers are expected to increase in winter and decrease in summer. Peak discharges (winter) are projected to increase as well. This could lead to increased flood risks for cities in the lower rivers (particularly in combination with sea level rise), upper rivers and IJsselmeer regions (MNP 2005). The formal design discharge ${ }^{2}$ corresponds to a 1/1250-year event. MNP (2005) projects the 1/1250-year discharge to increase by $3-10$ and $5-20 \%$ in 2050 for the Rhine and Meuse, respectively.

The magnitude and impacts of river flooding depend on geographical position (e.g. altitude of the land relative to the peak water level of the river, nearness to rivers), the predictability of the timing of the flood, the number of people in the area, whether the water velocity is sufficient to make buildings collapse, the speed by which the water level rises, the final water level and the possibilities and organisation of evacuations. Additionally, aspects such as the locations of critical and vulnerable objects and infrastructure, the reactive capacity to quickly changing situations and the ease and speed of water removal and recovery are important for the degree of damage and societal disruption (Wardekker et al. 2010).

In contrast, the magnitude and impacts of downpours depend on drainage systems (sewerage). Many municipalities accept water nuisance (on streets) at the most once every 2 years and have designed sewerage capacity accordingly. Current systems often cannot drain peak amounts of rain, resulting in local flooding (RIONED 2007a). Other factors affecting flooding impacts include surface water capacity, quality of sewer maintenance, the infiltration capacity of the surface (e.g. the amount of hardened/paved surface versus open soil and plants), buffer

\footnotetext{
2 The maximum amount of water that can flow through a river without flooding its hinterlands (in $\mathrm{m}^{3} / \mathrm{s}$, as measured at a specific point in the river). In terms of a design criterion, this is the minimum discharge that a river's flood defences are required by law to be able to cope with.
} 
and drainage capacity of open water and public spaces (squares, parks, streets), whether urban sewage and drainage systems are combined or separated, building materials used (e.g. easy/difficult to damage, clean) and street profile/ configuration (e.g. flat versus lowered, usable or not when flooded) (e.g. RIONED 2007a; CROW 2010).

\section{Governing heat stress and flooding: an analytical framework}

In this section, we will set out our analytical framework for analysing and explaining why and how urban planners govern or fail to govern heat stress and flooding. The section is structured according to our research questions formulated in the introduction and that address: a. Problem recognition; b. Proposed or implemented adaptation measures; c. Stimuli for and barriers to problem recognition and implementation of adaptation measures.

\section{Problem recognition}

Governance of climate change-related risks starts with the recognition of these risks. Regarding problem recognition, we consider the following questions: Are urban planners aware of the projected impacts of climate change on heat stress and flooding? Are intensified risks of heat stress and flooding considered problematic by urban planners and if so, why? Do planners consider these risks urgent enough to develop adaptation plans at short notice? and-perhaps more important-Are intensified heat stress and flood risks considered public problems, i.e. problems for which primarily urban planners are responsible?

\section{Adaptation measures}

Governance of heat stress and of flooding includes the way in which urban planners foresee and act upon these risks. What concrete adaptation measures are considered? For a classification of these, the following dimensions seem to be relevant:

- Time scale: plans and measures taken before climate change-related impacts occur ('proactive'), or plans and measures taken during or after such impacts occur ('reactive'). Proactive plans include retrofitting existing buildings and sewerage systems, whereas reactive plans include damage remedy and warning and information campaigns. Literature advocating adaptation seems primarily oriented towards the former types of measures, as these offer the most potential for preventing damage due to climate change;
- Spatial scale: individual buildings, street/quarter level or city level.

Tables 1 and 2 below specify adaptation measures that were identified in literature, classified according to the above dimensions. We drew from policy and planning literature (see supplementary materials document for sources). Some measures are contradictory; for instance, compact building has the advantage of using shade from buildings, but, at the same time, reduces wind speeds and, with that, urban ventilation. Other measures are adequate for adapting to both heat stress and flooding (e.g. green roofs). In particular, in plans for new construction, opportunities are foreseen for adaptation measures (e.g. CROW 2010), although these measures may also be implemented in existing neighbourhoods.

There are various ways in which these measures may be implemented (one can think of construction regulations for dwellings, investments by municipal authorities, covenants, voluntary measures, etc). It is conceivable that urban planners consider adaptation measures at neighbourhood or city levels in particular as their responsibility and leave adaptation measures at building level up to project developers, social housing corporations, property owners, retirement homes and nursing homes (Tompkins et al. 2010).

\section{Stimuli and barriers}

The literature referred to in the introduction suggests that not all municipalities actively anticipate heat stress and flooding associated with climate change. In Table 3, we provide an overview of possible stimuli for and barriers to the recognition of heat stress and flooding and the development of adaptation plans as mentioned in literature. We again draw from policy and planning literature on adaptation (again, see the supplementary materials document). The stimuli and barriers identified are sometimes interrelated and may reinforce or weaken one another.

\section{Governance of an intensification of heat stress and flooding: an empirical analysis}

Methods and data collection

In our empirical analysis of how Dutch urban planners perceive and deal with adaptation to heat stress and flooding, we mainly drew from two data sources. Key informant interviews with three experts based on our three research questions and presentations and discussions during workshops and conferences provided us with a general impression of how climate change-related increased risks 
Table 1 Adaptation measures for heat stress

\begin{tabular}{|c|c|c|c|}
\hline & Building & Street/quarter & City level \\
\hline $\begin{array}{l}\text { Proactive } \\
\text { measures }\end{array}$ & $\begin{array}{l}\text { Insulate buildings } \\
\text { Cooling systems (e.g. heat } \\
\text { pumps) } \\
\text { Sun screens, blinds and shutters } \\
\text { Provisions for heat disposal } \\
\text { (e.g. chimneys) } \\
\text { Building orientation (reduce } \\
\text { sun exposure) } \\
\text { Heavy building materials (high } \\
\text { solar thermal mass) } \\
\text { Green roofs (i.e. plant cover) } \\
\text { Green facades (i.e. plant cover) } \\
\text { Increased reflecting levels of } \\
\text { roofs (albedo) } \\
\text { Insurances (building owner) }\end{array}$ & $\begin{array}{l}\text { Open water, fountains, etc. } \\
\text { Vegetation (cooling due to } \\
\text { evaporation) } \\
\text { High albedo pavement instead of } \\
\text { asphalt } \\
\text { Creating optimal shading in building } \\
\text { orientation, compact building and } \\
\text { (big leaf) trees } \\
\text { Orientation and profile of streets } \\
\text { regarding wind direction (affecting } \\
\text { wind speed and urban ventilation) } \\
\text { Replacement of vulnerable groups } \\
\text { Monitoring and inspection } \\
\text { Warning systems and disaster } \\
\text { contingency plans }\end{array}$ & $\begin{array}{l}\text { Conduct research on heat stress } \\
\text { Anticipate possible peaks in deaths and } \\
\text { hospitalisations (access to/capacity of medical care) } \\
\text { Further: see under 'street/quarter' }\end{array}$ \\
\hline $\begin{array}{l}\text { Reactive } \\
\text { measures }\end{array}$ & $\begin{array}{l}\text { Cooling (air conditioning) } \\
\text { Medical care (building owner) }\end{array}$ & Wetting streets and roofs & $\begin{array}{l}\text { Information campaigns } \\
\text { Move to cooler areas } \\
\text { Further, see under 'street/quarter' }\end{array}$ \\
\hline
\end{tabular}

of floods and heat stress are generally perceived and acted upon in Dutch cities. More in-depth and contextualised insights were obtained through 13 in-depth interviews with urban planners of ten municipalities. Some of these municipalities are considered 'active adapters'; they have recognised increased risks of heat stress or flooding due to climate change as a (potential) policy problem, and activities have been undertaken to assess and map these risks and possibly also to develop adaptation strategies. The three key informant interviews provided an overview of these active municipalities (by Spring 2010 when we conducted our empirical work). During the 13 interviews, it became clear that the sample of active municipalities analysed were indeed 'active' in terms of our study (i.e. awareness of the climate change-induced risks; assessment and mapping of these risks; the development of adaptation plans or the consideration of doing so). We also interviewed planners from municipalities, which have not (yet) been active in adaptation to heat stress and flooding (June 2010). The reason for analysing these 'other' municipalities was mainly to explore the barriers to being active in assessing climate change-induced risks or developing adaptation plans. In addition, a comparison between the two groups of municipalities allowed for a verification of other (structural) factors that might explain the level of 'activeness'. These other municipalities are as far as possible comparable to the first set of municipalities in terms of vulnerability. Regarding vulnerability to heat stress, we mainly considered building density (see Sect. 2.1). Regarding vulnerability to flooding, we focussed on the position above/below sea level and proximity to rivers (see
Sect. 2.2). In addition, comparability regarding size was considered relevant, as in particular, small municipalities were expected to have few resources available for adaptation (see Sect. 3). Table 4 shows the municipalities examined; in some cases, both adaptation themes were relevant (in terms of vulnerability), in other cases only one.

By comparing the two samples of municipalities, we hoped to get a better insight into stimuli and barriers, as discussed in Sect. 3. We interviewed planners who were responsible for, or closely associated with, the two climate change-related risks. They worked in spatial planning and construction departments, water management departments, environmental or sustainability planning departments and departments specifically dealing with climate change (mitigation and/or adaptation). We did not interview officials from municipal health services, as our main interest was in proactive adaptation measures (see Tables 1, 2); however, in the interviews, we also asked about reactive measures. In the following subsections, we present the results of our empirical analysis. Most of the results are based on the interviews; if available, we supported statements or facts with references to scientific papers or policy documents. See "Appendix" for more information about the interviews and sources.

\section{Heat stress}

\section{(Stimuli for and barriers to) problem recognition}

Although heat stress is not a new phenomenon in the Netherlands, urban planners in the Netherlands generally 
Table 2 Adaptation measures for flooding

\begin{tabular}{|c|c|c|c|}
\hline & Building & Street/quarter & City level \\
\hline $\begin{array}{l}\text { Proactive } \\
\text { measures }\end{array}$ & $\begin{array}{l}\text { Downpours } \\
\text { Waterproof building, for example } \\
\text { Floor above street level } \\
\text { High thresholds } \\
\text { No crawl spaces } \\
\text { Waterproof plaster and membranes on } \\
\text { walls } \\
\text { Waterproof floors } \\
\text { Green roofs (i.e. plant cover) } \\
\text { Green facades (i.e. plant cover) } \\
\text { Water drainage (drainage in gardens, } \\
\text { gutters etc.) } \\
\text { Unpaved gardens (infiltration, water } \\
\text { retention) } \\
\text { River flooding } \\
\text { 'Floating' buildings } \\
\text { Pile-dwellings } \\
\text { River flooding and downpours } \\
\text { Insurances (building owner) }\end{array}$ & $\begin{array}{l}\text { Downpours } \\
\text { Seeping water 'screens' } \\
\text { Water permeable pavement instead of } \\
\text { asphalt and other measures for better } \\
\text { infiltration and water outlet } \\
\text { Lower water tables } \\
\text { Separation of rainwater and sewage } \\
\text { water plumbing } \\
\text { River flooding } \\
\text { Enhancing capacity of sluices and } \\
\text { weirs } \\
\text { Elevate urban areas } \\
\text { Additional flood defences (dykes or } \\
\text { buildings) or reinforcing existing } \\
\text { ones } \\
\text { Replacement of vulnerable buildings } \\
\text { and infrastructures } \\
\text { Disaster contingency plans (e.g. } \\
\text { temporary dykes) } \\
\text { River flooding and downpours } \\
\text { Monitoring and inspection } \\
\text { Warning systems } \\
\text { Evacuation plans } \\
\text { Extra green space } \\
\text { Water storage facilities (open water } \\
\text { such as pools) } \\
\text { Increase sewer capacity or enhanced } \\
\text { maintenance } \\
\text { Drainage systems } \\
\text { Dry pumps and other provisions for } \\
\text { water discharge and clean-up }\end{array}$ & $\begin{array}{l}\text { River flooding } \\
\text { Options for water storage and retention in } \\
\text { or near city } \\
\text { Evacuation plans } \\
\text { Ban on building in flood-prone areas } \\
\text { Compartmentalisation } \\
\text { River flooding and downpours } \\
\text { Conduct research } \\
\text { Information campaigns } \\
\text { Further: see under 'street/quarter' }\end{array}$ \\
\hline $\begin{array}{l}\text { Reactive } \\
\text { measures }\end{array}$ & $\begin{array}{l}\text { Downpours } \\
\text { Clean-up and damage remedy } \\
\text { River flooding and downpours } \\
\text { Clean-up and damage remedy } \\
\text { Medical care (building owner) }\end{array}$ & $\begin{array}{l}\text { River flooding and downpours } \\
\text { Warnings and information } \\
\text { Clean-up and damage remedy } \\
\text { Recovery plans }\end{array}$ & $\begin{array}{l}\text { River flooding and downpours } \\
\text { See under 'street/quarter' }\end{array}$ \\
\hline
\end{tabular}

seem not to be aware of it, let alone perceive it as a (emerging) problem (e.g. Breda and Hengelo). Our interviews suggest this is primarily related to the available knowledge on heat stress, which is characterised by a high level of abstraction (not allowing for local projections) and large uncertainties. However, the benefits - a reduction in adverse health effects - are also difficult to quantify and are not considered to be of primary interest to local politicians. Limited interaction between producers of knowledge on heat stress and urban planners contributes to the unknown character of heat stress. Municipalities such as Amsterdam, Hengelo and Lelystad do not expect that heat stress will occur, because of low building density or the presence of much open space or open water. Finally, the lack of national regulations regarding heat stress provides no incentive to be active regarding this phenomenon (although Amsterdam and Breda intend to explore the issue in the near future).

According to our interviews, project developers and social housing corporations do not pay much attention to heat stress, either, mainly because they are not familiar with this concept and its relation to buildings. More attention is paid to mitigation by enhancing energy efficiency (Roders et al. 2011). Our interviewees explain this by the few incentives these actors have to actively deal with heat stress; neither urban planners nor potential buyers 
Table 3 Stimuli for and barriers to adaptation

\begin{tabular}{|c|c|c|}
\hline & Stimuli & Barriers \\
\hline $\begin{array}{l}\text { Problem } \\
\text { recognition }\end{array}$ & $\begin{array}{l}\text { Political/institutional } \\
\text { Political will } \\
\text { Public or political support or pressure (e.g. a green- } \\
\text { minded municipal board) } \\
\text { Leadership (an actor taking the lead) } \\
\text { Resources } \\
\text { Subsidies from central government } \\
\text { Existence of innovative networks (e.g. EU projects) } \\
\text { Nature of the problem } \\
\text { Growing scientific evidence } \\
\text { Calamities (e.g. floods in the UK, } 2003 \text { heat wave) } \\
\text { Physical and geographical characteristics: } \\
\text { Located near river } \\
\text { Altitude (below sea level) } \\
\text { Density of buildings and other factors contributing to } \\
\text { 'heat island' effect or vulnerability to flooding } \\
\text { Concentration of vulnerable groups }\end{array}$ & $\begin{array}{l}\text { Political/institutional } \\
\text { Lack of political will (short-term politics) } \\
\text { No clarity about responsibilities for adaptation/framing adaptation } \\
\text { as a private problem } \\
\text { Competition from other planning problems } \\
\text { Institutional fragmentation } \\
\text { Lack of pressure from citizens or NGOs } \\
\text { Resources } \\
\text { Budget cuts } \\
\text { Lack of resources (in particular for small municipalities) } \\
\text { Nature of the problem } \\
\text { Denial of climate change (climate cynics) } \\
\text { Uncertainties in scientific evidence } \\
\text { Lack of insight into local impacts/difficulties in translating climate } \\
\text { change to the local level } \\
\text { Unawareness of the issue }\end{array}$ \\
\hline $\begin{array}{l}\text { Development of } \\
\text { adaptation } \\
\text { plans }\end{array}$ & $\begin{array}{l}\text { Political/institutional } \\
\text { Problem recognition and sense of urgency (see above) } \\
\text { Public or political support or pressure } \\
\text { Leadership (an actor taking the lead) } \\
\text { Political will } \\
\text { Resources } \\
\text { Subsidies from central government } \\
\text { Existence of innovative networks (e.g. EU projects) } \\
\text { Nature of the problem } \\
\text { 'Windows of opportunity' (e.g. plans for new } \\
\text { construction) }\end{array}$ & $\begin{array}{l}\text { Political/institutional } \\
\text { No problem recognition or sense of urgency } \\
\text { Distribution effects (winners/losers) } \\
\text { No clarity about responsibilities for adaptation } \\
\text { Not clear who should finance adaptation (or how) } \\
\text { Institutional fragmentation/complexity } \\
\text { Lack of cooperation from actors within the municipality or outside } \\
\text { it/lack of possibilities to steer these internal and external actors } \\
\text { Lack of public or political support } \\
\text { Competition from other planning problems } \\
\text { Resources } \\
\text { Lack of insight into possible adaptation measures } \\
\text { Lack of resources (in particular for small municipalities) } \\
\text { High costs/budget constraints } \\
\text { Nature of the problem } \\
\text { Inflexibility of urban area and high costs associated with adapting } \\
\text { existing buildings and public space } \\
\text { Path dependency (e.g. contracts with project developers that need to } \\
\text { be reopened) }\end{array}$ \\
\hline
\end{tabular}

Table 4 Case study municipalities

\begin{tabular}{lll}
\hline & Heat stress & Flooding (caused by river flooding and heavy downpours) \\
\hline Active & Arnhem (145,574 inhabitants) & Dordrecht (118,408 inhabitants) \\
& Rotterdam (587,134 habitants) & Rotterdam (587,134 habitants) \\
& Tilburg (203,464 inhabitants) & Tiel (41,070 inhabitants) \\
Other & Amsterdam (755,605 inhabitants) & Amsterdam (755,605 inhabitants) \\
& Breda (171,916) & Geldermalsen (26,289 inhabitants) \\
& Hengelo (80,925 inhabitants) & Lelystad (73,848 inhabitants) \\
& Lelystad (73,848 inhabitants) &
\end{tabular}

Inhabitants as at January 1, 2009. Source: CBS (2009). The sample includes large, medium-sized as well as small municipalities in the Netherlands 
or tenants of houses explicitly ask for heat stress-resistant buildings. Moreover, measures for reducing heat stress imply additional costs, and it is doubtful to what extent buyers accept these if these measures do not contribute directly to higher comfort. Since there are no formal regulations regarding heat stress, project developers and social housing associations will have to implement measures for adapting to heat stress on a voluntary basis. The expectation among our interviewees is that this will not take place on a large scale.

The few municipalities active in the area of heat stress (and analysed in our study) are in a stage of problem exploration and knowledge creation. For instance, in Rotterdam and Arnhem, a heat island effect of up to eight degrees difference in temperature between city centre and outskirts was measured (Klok et al. 2009). Only in Rotterdam have estimations been made about health impacts of (future increases in) heat stress. These estimations point to about 36 premature deaths annually because of heat stress; this number could double by 2050 (Daanen et al. 2010). There is no insight into the magnitude of other heat-related health impacts such as sleep deprivation. The stimuli for Rotterdam and Tilburg to be interested in heat stress are twofold: firstly, climate change was already on the political agenda, and heat stress could easily be linked to ongoing activities related to mitigation and adaptation, and secondly, both municipalities had access to funding from national research programmes on climate change. Additional stimuli for Tilburg were its existing ambitions to be a frontrunner regarding mitigation and adaptation, and concerns of the municipal health service about heat-related problems for elderly people. Arnhem's interest in heat stress originates from curiosity about the relevance of, and opportunities for, adaptation to climate change. Heat stress was focused on because it was a relatively new and unknown phenomenon. Similarly to Rotterdam and Tilburg, money and knowledge made available in an EU research programme further stimulated the exploration of the impacts of (future increases in) heat stress.

However, heat stress is not considered as an urgent policy problem in the above three 'active' municipalities, in part because citizens do not consider increases in temperature (and implicitly intensified heat stress risks) a problem (cf. Wolf et al. 2010). Heat stress only occurs over a short period of time, and only a small area is vulnerable to heat stress (namely, the city centre). In all three municipalities, other problems, such as mitigation, unemployment and traffic safety, receive more political attention and are considered more urgent.

\section{(Stimuli for and barriers to) adaptation measures}

Despite the lack of a sense of urgency, Arnhem, Rotterdam and Tilburg envisage the future implementation of measures aimed at reducing (future increases in) heat stress, in particular when restructuring areas sensitive to heat stress. These measures relate primarily to neighbourhoods and the city as a whole and are proactive rather than reactive, namely the provision of more public green space and vegetation and open water. In addition, in the three 'active' municipalities, the municipal health service provides or considers providing medical advice to general practitioners on heat-related remedies, especially for elderly people. However, the above measures are not meant to be dedicated measures for heat stress alone. More green space is considered a 'no regret' measure as it also contributes to improved spatial quality, environmental quality and to water storage. A reduction in heat stress is only considered as an additional benefit. As one interviewee stated, 'this is a solution looking for a problem'.

Barriers that the three municipalities face regarding the implementation of measures are the lack of a sense of urgency on the part of politicians and citizens, and budget constraints.

\section{Flooding}

\section{(Stimuli for and barriers to) problem recognition}

The Netherlands has an international reputation regarding water management (Meyer 2009). Water management plans are common in Dutch municipalities. About $60 \%$ of Dutch municipalities claim to anticipate increased flooding risks due to climate change (RIONED 2007b). Yet, based on our key informant interviews, case studies and desk research, the impression is that most municipalities are not very active in developing concrete adaptation plans, and if they do, their attention concentrates on sewerage systems (for which they bear responsibility) (RIONED 2007b). Some generic barriers that are observed include:

- The problem is not recognised, because of unawareness, its complexity and uncertainties;

- A lack of political priority due to the presence of problems that are considered more urgent (e.g. mitigation in Amsterdam);

- The expectation that problems related to heavy downpour will not occur (at least in the near future), for example due to the large capacity of the sewerage system, or because in the past land has been elevated (e.g. Amsterdam, Lelystad, Geldermalsen).

- A lack of incentives in terms of regulations or perceived benefits.

Nevertheless, several municipalities were found to actively anticipate future increases in flooding as a consequence of heavy downpour or river flooding. Urban planners in Dordrecht, Rotterdam and Tiel conceive it as 
follows: climate change will reinforce an already existing problem. The cities are located near rivers and below sea level. In Tiel, the impacts of climate change on flooding from rivers and rainfall are even expected to turn water nuisance into a large problem (in terms of safety and material damage). Yet, in all three municipalities, adaptation to an increased risk of flooding is explicitly conceived as an opportunity: measures such as more public green space and open water are expected to result in improved environmental and spatial quality. In this context, it is interesting to note that in Amsterdam, despite the claim of our interviewees that there is a lacking sense of urgency to adapt to an increased risk of flooding due to climate change, the provision of more open water and green public space is considered. This measure is primarily aimed at enhancing spatial and environmental quality, but the additional benefit of creating water buffers in the case of floods is explicitly recognised. In the case of Rotterdam, innovative adaptation measures such as multi-purpose dykes, water plazas and floating buildings are considered useful for profiling the city for its water management expertise as well as maintaining its attractiveness as a location for companies; long-term investments of companies may be relocated to less floodvulnerable areas if they consider cities as inadequately prepared for increased flood risks. In all three 'active' cities, additional perceived stimuli were 'windows of opportunity' in the form of plans for restructuring or new construction in flood-prone areas and money and knowledge made available in (inter)national research programmes, apart from past experiences with flooding from rivers and rainfall. Additional stimuli for Tiel included a mandatory 'water assessment' of a new construction area, pointing to large water problems (seeping water, infiltration capacity of urban surface and sewerage capacity) and complaints of inhabitants in a quarter that was built in the 1950s in a period when water was banned from the built environment. Finally, Tiel did not expect other actors to act. Project developers in particular were opposed to changing their construction and restructuring plans. Citizens seemed reluctant to take measures at building level (e.g. reduce the amount of paved surface on their territories)—in addition, the municipality feared that citizens would hold it responsible in the case of future flooding.

\section{(Stimuli for and barriers to) adaptation measures}

Measures that the three 'active' municipalities envisage (and have partly already planned) are primarily proactive and at neighbourhood level, such as additional open water, drainage systems and elevation of land. Long-term plans also include measures for the existing urban area, such as climate proof dykes, water permeable pavement, water plazas, more green public space, high capacity sewerage systems or a decoupling of rain water and sewerage systems and elevating land in new construction areas. Regarding areas around dykes, citizens are formally responsible for any damage due to flooding. However, urban planners in Rotterdam and Dordrecht feel they have some responsibility, because they have planned construction in these areas, and damage is not covered by insurance companies. Measures at building level are considered more complex to implement, as project developers and social housing corporations cannot (yet) be forced to implement these.

Plans are partly developed in cooperation with other public and private actors, in particular with regional water boards. Yet in all three cities, thus far, the municipality is the main responsible actor regarding adaptation to rainwater flooding, due to its legal responsibility for rain and sewage water management (although owners of land and buildings also have a legal responsibility regarding the management of rain water and protection against flooding). Actors other than water boards are not expected to take action, and citizens are not expected to be particularly aware of the problem, except perhaps for people living in areas around dykes.

During the interviews, a sense of urgency and political support were important stimuli for developing the adaptation plans; the other stimuli were discussed above. In Rotterdam, the plans for dealing with increased flooding are embedded in the already existing water management plan and the so-called Rotterdam Climate Proof programme initiated in order to profile Rotterdam internationally as a city with expertise in water management. However, the municipalities also face a few barriers, including uncertainties about the projections of increased flood risks, institutional fragmentation within the municipal organisation (in Rotterdam), the inflexibility of existing urban areas, the high costs involved, in combination with budget constraints and shortage of staff (in Tiel).

In municipalities where intensified flooding was considered to be potentially problematic, but where no plans were made, perceived barriers to implementing measures include a lack of resources and know-how (in particular for small and medium-sized municipalities), a lack of opportunities to combine measures for adaptation to new spatial developments (e.g. Geldermalsen) and high costs associated with adaptation to flooding, in particular in existing areas.

\section{Conclusions and discussion}

(Stimuli for and barriers to) problem recognition in Dutch urban areas

Despite scientific reasons for concern, a majority of Dutch urban planners do not seem to perceive heat stress (as such, 
as well as a possible increase as a consequence of climate change) as an urgent problem. In contrast, intensified flooding from rainfall and rivers seems more often recognised as a (potential) problem, although mainly in relation to sewerage systems. Nevertheless, the literature examined and our empirical analysis suggests a gap between the scientists' perceived urgency of proactive adaptation to climate change and the perceptions of the planners.

The most often mentioned barriers to problem recognition in the case of intensified heat stress are unawareness, a lack of local projections, a lack of legal obligations and, in some cases, the expectation that the phenomenon will not occur. Yet the main barrier seems to be the absence of a clear 'problem owner'. Project developers, social housing associations and house owners and tenants do not seem to consider heat stress as a problem (or, at least, their problem) and (perhaps therefore) neither do urban planners. The main stimuli for urban planners who have actively explored the phenomenon and who were interviewed in our study are curiosity, ambitions to be seen as 'adaptation leaders', support in the form of funding and knowledge and existing policies related to climate change to which heat stress could easily be linked. Yet these urban planners also conclude that heat stress is not a (urgent) problem.

The urban planners whom we interviewed indicated that stimuli to recognise potential problems related to intensified flood risks are as follows: the municipalities' responsibilities for rain and sewage water management, a sense of urgency due to a history of (near) floods, existing policies related to climate change and legally obligatory 'water assessments' for new construction plans. A lack of knowledge, a lacking sense of urgency, a lack of resources and a lack of legal obligations for unembanked areas were found to be the main barriers to problem recognition.

When comparing both risks, it seems that the fact that heat stress is often perceived as a new risk (although it is not) and forms an additional barrier to problem recognition compared to well-known risks such as flood risks.

(Stimuli for and barriers to) adaptation measures

in Dutch urban areas

Despite our observation that intensified heat stress is not perceived as a problem, various urban planners were found to have anticipated adaptation measures. Measures that are most often mentioned are more public green space and more open water. Yet the main rationale for considering these measures is not that they are proper means to reduce heat stress, but rather the other way around: heat stress is an additional justification for investing in more public green space and open water-measures that contribute to environmental and spatial quality. The main explanation for a lack of measures at street/quarter level is that actors responsible for these do not perceive (intensified) heat stress to be a problem. Other barriers to develop and implement adaptation measures include a lack of public pressure, a lack of resources and excessive costs involved in adjusting existing urban areas.

The majority of municipalities indicate that they take into account the future impacts of climate change on flooding from rainfall and rivers in their sewerage system plans. Their legal responsibility seems to be the main explanation. Some urban planners are also (considering) investing in more public green space and open water and other proactive measures at street/quarter or city level. Again, climate change impacts are merely an additional argument in favour of these measures than the reason per se. Other stimuli include ambitions for cities to be seen as adaptation leaders, the wish to remain an attractive location for companies, restructuring plans providing windows of opportunity, public pressure and unclear responsibilities for dwellings around dykes. Barriers include uncertainties about projections, institutional fragmentation, inflexibility of existing urban areas and a lack of restructuring plans, high costs and a lack of resources. A lack of measures at building level seems to be mainly explained by the reluctance of house owners and tenants to take action here.

\section{Looking ahead: general observations and reflections}

Our research provides a snapshot of how Dutch urban planners currently deal with (increased risks of) heat stress and flooding, of which the former in particular is a new phenomenon. We reflect on our findings based on the four reasons for concern about adaptation mentioned in Adger and Barnett (2009). The first concern, related to the scale of change and its interconnectedness (Adger and Barnett 2009 , p. 2800), refers to the potential magnitude of climate effects and its impact on societies. The descriptions of heat stress and flooding challenges for Dutch urban areas as portrayed in Sect. 2 clearly demonstrate the risk that floods in particular pose to a low-lying country in a delta, and the need for action sooner rather than later. The second concern, about a lack of adaptive action despite the existence of sufficient adaptive capacity (Adger and Barnett 2009), is also observed in our study. Regarding heat stress, a lack of problem ownership seems to be the most important barrier to action. This corresponds with findings in literature, which suggest that vagueness of responsibilities is a key barrier to adaptation action (Biesbroek et al. 2010; Carter 2011; Dovers and Hezri 2010; Fünfgeld 2010; Storbjörk 2010). In their dealings with flood risk, municipalities tend to rely on the national government to take large-scale flood-prevention measures. The actions local authorities do take tend to be of a small-scale and no-regrets nature: they serve multiple societal goals rather than being tailored 
towards specific adaptation action. In Germany, the UK and elsewhere similar observations are made (BerrangFord et al. 2011; Matzarakis and Endler 2010; Otto-Banaszak et al. 2011; Tompkins et al. 2010). Considering the above, we suggest that among local planners, the salience of climate change impacts is currently not or to a limited extent acknowledged, which may hamper timely and sufficient adaptation. Further exploration of specific local implications of climate change, of local vulnerabilities and resilience and of multi-purpose adaptation strategies would be useful. While considerable uncertainties will remain, such analyses should allow local planners to better envisage the specific bottlenecks, options and adaptation needs of their cities. The third reason relates to maladaptation in the sense that adaptation action can be detrimental to other sustainability goals (Adger and Barnett 2009, p. 2802). The tendency towards multi-purpose no-regrets measures by Dutch urban planners, at least in the active municipalities, suggests the opposite; we should rather critically assess the extent to which these measures would contribute to making the Netherlands more climate proof. Nevertheless, this concern does point to the need for continued attention to the 'mainstreaming' of adaptation policy goals into the broader sustainability agenda (Berrang-Ford et al. 2011; Biesbroek et al. 2010; Urwin and Jordan 2008), particularly in the case of the ongoing urban renewal that will take place in the coming decades (Van de Ven et al. 2011), and certainly beyond the range of just the active municipalities. The fourth concern is that of the potential neglect of the social context in which adaptation action takes place (Adger and Barnett 2009, p. 2803), especially taking into account the perspectives of those affected by climate effects and, more generally, citizens as the recipients of policy. This study confirms that in Dutch practice, the development of adaptation policy and plans rests with public authorities at different levels of responsibility (national, provincial and local governments and water boards). Our study shows that private actors are only involved to a limited extent in local adaptation policy, and therefore, the general public is hardly aware of flood induced risks (Terpstra and Gutteling 2008). More generally speaking, our findings appear to point towards the need for an increased understanding of the governance of climate adaptation, specifically related to the questions of responsibility and the public-private divide. We encourage future research into the scope of governance arrangements for climate adaptation. Furthermore, we suggest research to help to achieve more understanding of local projections of climate impacts, and of strategies for successful implementation of adaptation measures. This way we hope the gap between scientists and urban planners regarding the 'why' and the 'how' of climate adaptation can be reduced, and some of these adaptation concerns addressed.
Acknowledgments The authors would like to thank Tina Newstead for her language corrections.

Open Access This article is distributed under the terms of the Creative Commons Attribution License which permits any use, distribution, and reproduction in any medium, provided the original author(s) and the source are credited.

\section{Appendix}

Case studies: positions of our interviewees (anonymous)

- Heat stress

- Amsterdam: senior planner

- Arnhem: senior policy advisor public space; project leader heat stress project

- Breda: policy advisor public space

- Hengelo: team leader sustainability

- Lelystad: policy maker climate change

- Rotterdam: advisor sustainable development

- Tilburg: programme manager energy and climate.

- Flooding

- Amsterdam: senior planner

- Dordrecht: strategic policy advisor

- Geldermalsen: legal advisor environmental planning

- Lelystad: policy maker climate change

- Rotterdam: advisor water management and coordinator adaptive construction

- Tiel: project leader urban development and programme manager.

\section{Respondents key informant interviews}

- Mr. H. Gastkemper (director RIONED (a cooperation between public and private actors involved in urban sewerage systems); chair of the working group of Adaptation public spaces CROW (platform for knowledge exchange in the fields of infrastructure, transport and traffic and public space) (heat stress and flooding)

- Mr. V. Kuypers, M.Sc. (researcher Alterra, Wageningen University; independent consultant) (heat stress and flooding)

- Prof. Chr. Zevenbergen (Dura Vermeer; Delft University of Technology) (flooding).

\section{Workshops and conferences attended}

- Rotterdam, 20 May 2010, Het Groene Lente Festival, parallel session on climate adaptation strategies for 
municipalities and project developers, organised by NEPROM, association of Dutch project developers (heat stress and flooding)

- Arnhem, 26 May 2010, Hitte eiland en hitte stress in Nederland, Villa Sonsbeek, Arnhem, organised by the municipalities of Arnhem, Nijmegen, Rotterdam and Tiel, CROW, the National Research Programme Knowledge for Climate and the National Research Programme Climate changes Spatial Planning (heat stress).

Questionnaire interviews with urban planners

\section{Problem perception heat stress or flooding}

- Does your municipality expect an increase in heat stress or flooding as a consequence of climate change?

- If yes, is it considered a problem and if so, why and for whom?

- Within what time horizon is an increase in heat stress or flooding expected?

- How is the frequency of tropical days or heavy downpours expected to change?

- What are vulnerable areas or target groups?

- What consequences are foreseen in terms of health, material damage etc.?

- What is the basis of these estimations (research)?

- What have been the main triggers of the recognition of increased risks of heat stress or flooding as a consequence of climate change? And what have been barriers? (show table with stimuli and barriers from the literature).

- If no, why not?

- Is no increase in heat stress or flooding expected?

- Are these risks absent (e.g. because of excess sewer capacity or sufficient urban ventilation)?

- Is it not considered the responsibility of the municipality?

- What are the main reasons for not recognising increases in heat stress or flooding as a problem? (show table with barriers from the literature).

Responses to increases in heat stress or flooding

- Have adaptation plans been developed regarding increased heat stress or flooding as a consequence of climate change?

- If no, what ideas exist to deal with these two risks associated with climate change?

- What is the preferred approach: planning based on precautionary considerations (i.e. proactive) or a more incremental approach (waiting for more certainty of knowledge of these risks before developing plans)?

- In what stage of planning is the municipality at this moment?

- Who are involved in the adaptation planning process? What roles have been assigned to actors involved and why?

- If no, how can the adaptation plans be characterised?

- What are acceptable norms for heat stress or flooding?

- Who are (have been) involved in the adaptation planning process and the implementation of these plans? What roles have been assigned to actors involved and why?

- To what extent has implementation of the adaptation plans been secured by political support, commitment of stakeholders, budgets, inter-sectoral coordination etc.?

- How is inter-sectoral coordination organised?

- In what areas are adaptation measures foreseen (existing urban areas, new urban developments, restructuring areas etc.) and why there?

- What types of adaptation measures are considered or implemented? (show table with measures identified in the literature) Why these and not others?

- What have been the main stimuli for and barriers to the development of adaptation plans (show table with stimuli and barriers from the literature)

- What has been the added value of participation in national adaptation research projects? How much support (in terms of knowledge, budgets etc.) has been received? What has been the practical value of this support?.

Other sources employed for the case studies (policy documents, research reports etc.)

\section{General background documents}

- Woestenburg, M. (n.d.) Klimaat in de stad (city climate). Alterra Wageningen University, Wageningen.

- Future Cities (n.d.) Stadsregio's weten om te gaan met voorspelde effecten van klimaatverandering. http:// www.future-cities.eu/fileadmin/user_upload/project_ desc/Poster_FutureCitiesNL.pdf

- Stadsregio Arnhem-Nijmegen (n.d.), Groene daken (green roofs). Voor luchtkwaliteit en klimaat, Eureka project, http://www.destadsregio.nl/images1/stadsregio/ bestanden/san0059_BoekjeGroeneDaken_06_webver sie.pdf 
- Stichting Rioned (n.d.) Goede zorg voor afvalwater (managing sewage water), regenwater en grondwater. Rioned, Ede.

- Stichting Rioned (2010) Bestuurdersinformatie: afkoppelen van regenwater (separating rain water discharge from the sewerage system). Rioned, Ede.

- Stichting Rioned (2010) De openbare ruimte en het riool; een geïntegreerd systeem (connecting sewerage systems and public space). Rioned, Ede.

- Stiching Rioned (2010) Klimaatverandering, hevige buien en riolering (climate change and sewerage systems). Rioned, Ede.

\section{Rotterdam}

- Rotterdam (2006) Rotterdam Groen van Boven Toepassing van groene daken in Rotterdam (green roof policy). Municipality of Rotterdam.

- Rotterdam (2007) Stadsvisie, ruimtelijke Ontwikkelingsstrategie 2030 (Spatial development strategy). Municipality of Rotterdam.

- Rotterdam (2007) Waterplan2, Werken aan een aantrekkelijke stad (water management plan). Municipality of Rotterdam and the regional water boards.

- Rotterdam Climate Initiative (2007) Actieprogramma en doelen 2007-2010 (programme 2007-2010). Municipality of Rotterdam and partners.

- Rotterdam Climate Proof (2008) The Rotterdam challenge on water and climate adaptation. Municipality of Rotterdam.

- Rotterdam Climate Proof (2009) Adaptation programme, Municipality of Rotterdam.

- Rotterdam (2009) Klimaat and Groen toolbox. Municipality of Rotterdam.

\section{Tiel}

- Tiel (n.d.) Tiel East drier and nicer, preferred scenario for the fighting of water nuisance. Municipality of Tiel.

\section{Arnhem}

- Future Cities (n.d.) Naar klimaatbestendige steden in de Stadsregio Arnhem Nijmegen (climate proofing Anrhem and Nijmegen), Eureka project, http://www. destadsregio.nl/publicaties_detail.asp?PubID=161.

- Future Cities (n.d.) Analyse van het hitte-eilandeffect op Arnhem (analysis of the urban heat island effect in Arnhem), Eureka project, http://www.future-cities.eu/ uploads/media/Future_Cities_Analyse_hitte_eilandeff ect_op_Arnhem.pdf.
Tilburg

- Tilburg (2008) Eerste Klimaatprogramma Tilburg, naar een klimaatneutrale en klimaatbestendige stad. Periode 2009-2012, de eerste etappe: 'Start van een lokale klimaatkentering' (First climate mitigation and adaptation plan 2009-2010), municipality of Tilburg.

- Scheinder, H., D. Dicke and V. Rovers (2007) Adaptatiescan Tilburg. Klimaatadaptatie in de Hotspot (adaptation 'scan'). By order of the municipality of Tilburg, BuildDesk Nederland, Delft.

\section{Dordrecht}

- Dordrecht (2009) Waterplan Dordrecht 2009-2015. Samen werken aan een veilig, mooi en vitaal eiland van Dordrecht (water plan 2009-2015). Municipality of Dordrecht and the water board Hollandse Delta.

- Dordrecht (2009) Dordrecht werkt aan hoogwaterbeheer (river flood risk management plan), http://cms.dor drecht.nl/Dordrecht/up/ZeclyifIwB_Dordrecht_werkt_ aan_hoogwaterbeheer.pdf.

\section{References}

Adger N, Barnett J (2009) Four reasons for concern about adaptation to climate change, commentary. Environ PlanA 41(12): 2800-2805

Bassett E, Shandas V (2010) Innovation and climate action planning. J Am Plan Assoc 76(4):435-450

Bernard SM, McGeehin MA (2004) Municipal heat wave response plans. Am J Public Health 94(9):1520-1522

Berrang-Ford L, Ford JD, Paterson J (2011) Are we adapting to climate change? Glob Environ Change 21(1):25-33

Biesbroek GR, Swart RJ, Carter TR, Cowan C, Henrichs T, Mela H, Morecroft MD, Rey D (2010) Europe adapts to climate change: comparing national adaptation strategies. Glob Environ Change 20(3):440-450

Bulkeley H (2009) Planning and governance of climate change. In: Davoudi S, Crawford J, Mehmood A (eds) Planning for climate change. Strategies for mitigation and adaptation for spatial planners, London, Earthscan, pp 284-296

Bulkeley H (2010) Cities and the governing of climate change. Annu Rev Environ Res 35(1):229-253

Butler CD, Harley D (2009) Primary, secondary and tertiary effects of eco-climatic change: the medical response. Postgrad Med J 86(1014):230-234

Carter JG (2011) Climate change adaptation in European cities. Curr Opin Environ Sustain 3(3):193-198

CBS (2009) Demografische kerncijfers per gemeente 2009. Statistics Netherlands, The Hague/Heerlen. Available from http://www. cbs.nl/NR/rdonlyres/0A28851B-BF48-4EDF-A5E6-1D464E73C D1D/0/2009b55pub.pdf

CROW (2010) Aanpassen openbare ruimte aan klimaatverandering. Gemeenten aan de slag met klimaatadaptatie. CROW, Ede

Daanen HAM, Simons M, Janssen SA (2010) De invloed van hitte op de gezondheid, toegespitst op de stad. TNO, Rotterdam 
Demeritt D, Langdon D (2004) The UK climate change programme and communication with local authorities. Glob Environ Change 14(4):325-336

Dovers SR, Hezri AA (2010) Institutions and policy processes: the means to the end of adaptation. Wiley interdisciplinary review: climate change 1(2):212-231

Fischer PH, Brunekreef B, Lebret E (2004) Air pollution related deaths during the 2003 heat wave in the Netherlands. Atmos Environ 38:1083-1085

Fünfgeld H (2010) Institutional challenges to climate risk management in cities. Curr Opin Environ Sustain 2(3):156-160

García-Herrera R, Diaz J, Trigo RM, Luterbacher J, Fischer EM (2010) A review of the European summer heat wave of 2003. Critical Rev Environ Sci Technol 40(4):267-306

Garssen J, Harmsen C, de Beer J (2005) The effect of the summer 2003 heat wave on mortality in the Netherlands. Eurosurveillance 10(7):165-168

Gemeentewerken Rotterdam (2011) Hittestress in Rotterdam. Rotterdam Public Works Department, Rotterdam

Groot MI, Wielders LML, van de Vreede GJ (2008) Relatie tussen mitigatie en adaptatie op gebouwniveau; Inventarisatie van tegenstrijdigheden en synergismen. CE Delft, Delft

Huynen MMTE, van Vliet AJH (2009) Klimaatverandering en gezondheid in Nederland. Nederlands Tijdschrift voor Geneeskunde 153:A1515

Huynen MMTE, Martens P, Schram D, Weijenberg MP, Kunst AE (2001) The impact of heat waves and cold spells on mortality rates in the Dutch population. Environ Health Perspect 109(5): $463-470$

Huynen MMTE, Hollander AEM de, Martens P, Mackenbach JP (2008) Mondiale milieuveranderingen en volksgezondheid: stand van de kennis. National Institute for Public Health and the Environment (RIVM), Bilthoven

IPCC (2007) Climate change 2007: impacts, adaptation and vulnerability. Cambridge University Press, Cambridge

Kabat P, van Vierssen W, Veraart J, Vellinga P, Aerts J (2005) Climate proofing the Netherlands, commentary. Nature 438: 283-284

Klok EJ, Zwart S, Verhagen H, Mauri E (2009) The heat island of Rotterdam derived from satellite imagery, paper presented at the SENSE symposium climate proofing cities, Amsterdam, 1 Dec 2009

KNMI (2009) Climate change in the Netherlands: supplements to the KNMI'06 scenarios. Royal Netherlands Meteorological Institute (KNMI), De Bilt

Kovats RS, Ebi KL (2006) Heat waves and public health in Europe. Eur J Pub Health 16(6):592-599

Matzarakis A, Endler C (2010) Climate change and thermal bio climate in cities: impacts and options for adaptation in Freiburg, Germany. Int J Biometeorol 54(4):479-483

Meehl GA, Tebaldi C (2004) More intense, more frequent, and longer lasting heat waves in the 21st century. Science 305:994-997

Meyer H (2009) Reinventing the Dutch delta: complexity and conflicts. Built Environ 35(4):432-451

MNP (2005) The effects of climate change in the Netherlands. Netherlands Environmental Assessment Agency, Bilthoven

Mulder KF, Enserink B, Salcedo-Rahola B (2009) The neglected effects of climate change, paper presented at the 15th international sustainable development research conference, July 5-8, Utrecht University, Utrecht
Otto-Banaszak I, Matczak P, Wesseler J, Wechsung F (2011) Different perceptions of adaptation to climate change: a mental model approach applied to the evidence from expert interviews. Reg Environ Change 11(2):217-228

PBL (2009) Wegen naar een klimaatbestendig Nederland. Netherlands Environmental Assessment Agency, Bilthoven

PBL (2010) Correction wording flood risks for the Netherlands in IPCC report. Netherlands environmental assessment agency, Bilthoven. Available from http://www.pbl.nl/en/dossiers/Climate change/content/correction-wording-flood-risks.html

RIONED (2007a) Climate change, heavier rainstorms and the urban drainage system. RIONED Foundation, Ede. Available from http://www.riool.net/riool/shopping/product/ show $\cdot$ do? instanceid $=130 \&$ itemid $=4764 \&$ style $=$ default

RIONED (2007b) Onderzoek regenwateroverlast in de bebouwde omgeving. RIONED Foundation, Ede. Available from http:// www.riool.net/riool/binary/retrieveFile?instanceid=20\&itemid= 3197\&style $=$ default

Roders MJ, Straub A, Visscher HJ (2011) Climate change effects on living quality; awareness of housing associations. In: Wamelink JWF, Geraerdts RP, Volker L (eds) Proceedings of the international conference on management and innovation for a sustainable built environment. Delft University of Technology, Delft

Salcedo Rahola B, van Oppen P, Mulder K (2009) Heat in the city. An inventory of knowledge and knowledge deficiencies regarding heat stress in Dutch cities and options for its mitigation. Report commissioned by the national research programme climate changes spatial planning. Delft University of Technology, Delft

Storbjörk S (2010) It takes more to get a ship to change course': barriers for organizational learning and local climate adaptation in Sweden. J Environ Policy Plann 12(3):235-254

Terpstra T, Gutteling JM (2008) Households' perceived responsibilities in flood risk management in The Netherlands. Water Res Dev 24(4):555-565

Tompkins EL, Adger WN, Boyd E, Nicholson-Cole S, Weatherhead K, Arnell N (2010) Observed adaptation to climate change: UK evidence of transition to a well-adapted society. Glob Environ Change 20(4):627-635

Urwin K, Jordan A (2008) Does public policy support or undermine climate change adaptation? Exploring policy interplay across different scales. Glob Environ Change 18(1):180-191

Van de Ven F, Van Nieuwkerk E, Stone K, Zevenbergen C, Veerbeek W, Rijke J, Van Herk S (2011) Building the Netherlands climate proof. Urban areas. Report 1201082-000-VEB-0003. Deltares/ UNESCO-IHE, Delft/Utrecht

Van den Hurk B, Klein Tank A, Lenderink G, van Ulden A, van Oldenborgh GJ, Katsman C, van den Brink H, Keller F, Bessembinder J, Burgers G, Komen G, Hazeleger W, Drijfhout S (2006) KNMI climate change scenarios 2006 for the Netherlands. Royal Netherlands Meteorological Institute (KNMI), De Bilt

Wardekker JA, de Jong A, Knoop JM, van der Sluijs JP (2010) Operationalising a resilience approach to adapting an urban delta to uncertain climate changes. Technol Forecast Soc Chang 77(6):987-998

Wheeler SM (2008) State and municipal climate change plans. J Am Plann Assoc 74(4):481-496

Wolf J, Adger WN, Lorenzoni I, Abrahamson V, Raine R (2010) Social capital, individual responses to heat waves and climate change adaptation: an empirical study of two UK cities. Glob Environ Change 20(1):44-52 